Табачук Назарій Петрович магістр міжнародного права, молодший науковий співробітник з міжнародного права, провідний спеціаліст відділу ринків виробничих галузевих товарів, Департамент досліджень і розслідувань ринків виробничої сфери, фармацевтики та рітейлу, Антимонопольний комітет України, вул. Митрополита Василя Липківського, 45, м. Київ, 03035, тел.: (044) 251-62-11, e-mail: tabachuk.nazarii@gmail.com, https://orcid.org/0000-0002-1819-5593.

\title{
ПЕРЕГЛЯД РІШЕНЬ ЄВРОПЕЙСЬКОЇ КОМІСІЇ СУДОМ ЄС: АКТУАЛЬНІ СПРАВИ
}

Анотація. У даній статті проаналізовано актуальні справи, розглянуті Судом $\mathrm{EC}$, та виявлено основні тенденції у відповідній практиці, що може слугувати орієнтиром для Антимонопольного комітету України та національних судів для покращення власної практики прийняття рішень у сфері конкуренції, адже ринок товарів і послуг не стоїть на місці і потребує постійного удосконалення регулювання конкуренції 3 метою недопущення знаходження суб'єктами господарювання лазівок у законодавчій та інституційній системах.

Встановлено, що крім основного акценту на благополуччі споживачів, європейська судова практика окреслила мету підтримки ефективної конкурентної структури. Хоча ці дві мети часто перетинаються, акцент на конкурентній структурі створює додатковий нюансовий аспект. Європейські суди давно вважають, що конкуренційне право спрямоване на регулювання не тільки дій, які можуть завдати безпосередньої шкоди споживачам, але і дій, що завдають їм шкоди через їх вплив на ефективну структуру конкуренції.

Безліч цілей у сфері конкуренції і їх становище в рамках більш широких нормативних цінностей $\mathrm{CC}$, безсумнівно, є складним. Здебільшого, Суд $€ \mathrm{C}$ та Європейська Комісія послідовно розробляють основні цілі законодавства $Є С$ про конкуренцію, використовуючи економічний та правовий аналіз для оптимізації втручання в рамках меж, встановлених положеннями установчих Договорів, зокрема, Договору про функціонування Свропейського Союзу.

Встановлено, що у галузі антимонопольного права роль Суду схематично двояка: по-перше, забезпечення ефективного й однакового застосування законодавства Союзу і запобігання будь-яким розбіжностям у тлумаченні. Це в основному здійснюється за допомогою попередніх рішень з питань, переданих судами держав-членів. По-друге, Суд має право перевіряти законність діяльності 
Комісії, наприклад рішення Комісії про притягнення до відповідальності за порушення законодавства про конкуренцію можуть бути оскаржені у Суді загальної юрисдикції СС. Суд, у разі необхідності, розглядає апеляції на рішення Загального суду і тим самим сприяє розвитку правозастосовної практики у сфері конкуренції.

Ключові слова: конкуренційне право, Свропейський Союз, Свропейська Комісія, Суд загальної юрисдикції ЄС, монопольне (домінуюче) становище.

Tabachuk Nazarii Petrovych Master of International Law, Junior Researcher in International Law, leading specialist of the Industrial Products Markets Division, Department of Research and Investigation of Industrial Markets, Pharmaceuticals and Retail, Antimonopoly Committee of Ukraine, Mytropolyta Vasylia Lypkivskogo St., 45, Kyiv, 03035, tel.: (044) 251-62-11, e-mail: tabachuk.nazarii@gmail.com, https://orcid.org/0000-0002-1819-5593.

\section{REVIEW OF THE DECISIONS OF THE EUROPEAN COMMISSION BY THE COURT OF JUSTICE OF THE EUROPEAN UNION: LATEST CASES}

Abstract. This article analyzes latest cases considered by the Court of Justice of the European Union, and identifies the main trends in relevant practice, which can serve as a guideline for the Antimonopoly Committee of Ukraine and national courts to improve their own decision-making practice in the competition sphere. After all, the market for goods and services does not stand still and requires constant improvement of competition regulation in order to prevent business entities from finding loopholes in the legislative and institutional systems.

It was found that in addition to the main focus on consumer welfare, European jurisprudence outlined the goal of maintaining an effective competitive structure. While these two goals often overlap, the emphasis on competitive structure creates an additional nuance aspect. European courts have long believed that competition law was aimed at regulating not only actions that may directly harm consumers, but also actions directed against them through their influence on the effective structure of competition.

The many competition objectives and their position within the broader EU normative values are undoubtedly complex. Basically, the Court of Justice of the European Union and the European Commission consistently develop the main objectives of EU competition law, using economic and legal analysis to optimize interventions within the boundaries set by the provisions of constituent treaties, in particular the Treaty on the Functioning of the European Union.

It was found that in the field of competition law, the role of the EU court is schematically twofold: first, ensuring the effective and uniform application of the 
legislation of the EU and preventing any differences in interpretation. This is mainly done through previous judgments on matters referred by the courts of the Member States. Secondly, the Court has the right to check the legality of the activities of the Commission, for example, the decision of the Commission to prosecute for violation of competition law can be appealed to the General Court. The EU court, if necessary, hears appeals against decisions of the General court and thereby contributes to the development of law enforcement practice in the field of competition.

Keywords: competition law, the European Union, the European Commission, the General Court, a dominant position.

Постановка проблеми. Враховуючи, що наша держава обрала курс на євроінтеграцію та у зв'язку з цим повинна привести національне законодавство у відповідність до стандартів СС, вбачається доцільним провести аналіз не тільки антимонопольного законодавства $€ С$, а й діяльності Суду Європейського Союзу. Галузь антимонопольного права в Україні наразі потребує удосконалення шляхом як інституційних так $\mathrm{i}$ законодавчих змін. Сама історія розвитку антимонопольного права ЄС багата на приклади, того яким чином необхідно проводити реформи.

Аналіз останніх досліджень і публікацій. Серед зарубіжних науковців, які досліджували відповідне питання можна виділити наступних: М. Коппола, П. Акман, Дж. Алісон, М. Грілло, Дж. Кларке, В. Кора, Х.А. Косма, І. Ліанос, I. Махер. На вітчизняному рівні конкуренційне право СС та практику Суду СС досліджували В. Андрущенко, Т. Комарова, В. Лук'янець, К. Смирнова тощо. Разом 3 тим дослідження новітньої практики Суду СС з урахуванням сучасних реалій та розвитку технологій достатнім чином не здійснювалося.

Мета статті - визначення ролі Суду СС з перегляду рішень Європейської Комісії щодо справ про порушення європейського конкуренційного законодавства для розвитку відповідної практики та виявлення основних тенденцій у справах Суду ЄС на сучасному етапі.

Виклад основного матеріалу. Через рік Свропа відзначатиме 65-ту річницю підписання Римського договору (1957). Ефективна і сильна політика у галузі антимонопольного права завжди була одним з наріжних каменів Свропейського економічного співтовариства, а потім - Свропейського Союзу. Безсумнівно, що законодавча база останнього допомагає підтримувати кращу конкуренцію між суб'єктами господарювання в ЄС. Це, зокрема, веде до підвищення якості та розширення вибору продуктів і послуг, зниження цін, більшої кількості інновацій i появи сильних конкурентів на світових ринках з боку СС. Інституції $Є \mathrm{C}$ тісно співпрацюють 3 метою, щоб всі ці вищезгадані цілі були належним чином досягнуті. У той час як Свропейський парламент, Рада СС працюють у сфері 
законодавства про конкуренцію та відіграють важливу роль у формуванні політики у галузі конкуренції загалом, забезпеченням належного застосування i тлумачення норм антимонопольного законодавства СС займається Європейська Комісія, а в разі юридичного спору - Суд Свропейського Союзу. Однією 3 найважливіших цілей батьків-засновників Свропейського співтовариства було створення єдиного ринку. Для цього необхідно було створити конкурентоспроможну, прозору та досить стандартизовану нормативно-правову базу конкуренційного права. Щоб уникнути різного тлумачення конкурентного законодавства $\mathrm{CC}$, яке могло відрізнятися від національних судів, Європейській Комісії довелось взяти на себе роль центрального виконавчого органу.

Суд ЄС (Суд) є основним дійовим органом у розробці єдиної практики тлумачення законодавства $\mathrm{CC}$, в тому числі у сфері конкуренції. Оскільки ні суди держав-членів, ні інші міжнародні суди не мають права офіційно тлумачити правові норми ЄС, роль Суду стає надзвичайно важливою у правовій структурі ЄС. 3 моменту свого створення у 1952 році, його місією завжди було забезпечення дотримання законодавства при тлумаченні та застосуванні положень основних договорів Співтовариства.

Не слід забувати, що важливість практики Суду має два аспекти. 3 одного боку, Суд виносить рішення, які важливі для конкретних справ і мають наслідки для сторін цих справ. 3 іншого боку, при винесенні судових рішень Суд надає тлумачення, які мають значення для інших справ: його рішень надалі дотримуються національні антимонопольні органи, національні суди, Комісія i сам Суд у своїй судовій практиці. Варто зазначити, що регулювання у сфері конкуренції зазнало чималих змін протягом останнього десятиліття. В даний час через ряд об'єктивних причин Суд отримує набагато менше справ щодо конкуренції, ніж раніше.

Підвищення рівня благополуччя споживачів і запобігання заподіянню шкоди споживачам уже давно вважаються головними цілями законодавства про конкуренцію. Свого часу Суд загальної юрисдикції ЄС (Загальний суд) зазначив: «Кінцева мета положень, спрямованих на те, щоб конкуренція не була спотворена на внутрішньому ринку, полягає у підвищенні добробуту споживачів ... Законодавство про конкуренцію і політика у сфері конкуренції ... мають незаперечний вплив на конкретні економічні інтереси кінцевих споживачів, які купують товари або послуги». Суд роз'яснив, що благополуччя споживачів може бути підірване як прямо, так і опосередковано, підтвердивши, що норми про конкуренцію охоплюють «не тільки ті дії, які безпосередньо шкодять споживачам, але також і дії, які завдають споживачам шкоду в результаті їх впливу на конкуренцію» [1].

У справі T-Mobile Суд $\mathrm{CC} \mathrm{уточнив,} \mathrm{що} \mathrm{законодавство} \mathrm{про} \mathrm{конкуренцію}$ 
покликане захищати не тільки безпосередні інтереси окремих конкурентів або споживачів, але також захищати структуру ринку i, отже, конкуренцію як таку. Суд також додав, що узгоджені дії можуть розглядатися як такі, що мають антиконкурентну мету, навіть якщо немає прямого зв'язку між цими діями i споживчими цінами. Аналогічним чином у цьому рішенні зазначалось, що захист структури ринку побічно також захищає споживачів, тому що там, де конкуренція спотворена, слід побоюватися настання негативних наслідків і для споживачів [2].

У справі Konkurrensverket $v$ TeliaSonera Sverige [3] Суд наголосив на важливості запобігання «спотворенню конкуренції на шкоду інтересам суспільства, окремих суб’єктів господарювання і споживачів, забезпечуючи тим самим благополуччя Свропейського Союзу». Відповідно до цього підходу, Загальний суд зазначив у справі Intel Corp. v Commission [4], що «Комісія не зобов'язана доводити ні наявності прямої шкоди споживачам, ні причиннонаслідкового зв’язку між такою шкодою та діями, про які йде мова в оспорюваному рішенні ... Стаття 102 Договору про функціонування Свропейського Союзу (ДФСС) регулює не тільки практику та дії, які можуть завдати шкоди споживачам безпосередньо, але також і ті випадки, які завдають шкоди внаслідок впливу на ефективну конкурентну структуру ринку».

Однак, акцент на добробуті споживачів не є центральним у судовій практиці європейських судів, де переважає думка, що обмеження конкуренції або зловживання домінуючим становищем мають місце тоді, коли відповідна діяльність завдає шкоди конкурентному процесу. Докази наявності заподіяної шкоди споживачам не потрібні [5].

Тим не менш, слід розуміти, що таке тлумачення, можливо, отримує підтримання не усіма суддями. Наприклад, у справі France Te'le'com [6] один iз суддів у своїй окремій думці вказав, що встановлення хижацького ціноутворення може бути досягнуто тільки при наявності доказів того, що домінуючий суб'єкт господарювання зможе покрити понесені витрати шляхом встановлення монопольно високої ціни. Крім того, у рішенні щодо вище зазначеної справи вказувалось, що у разі відсутності у такого суб'єкта господарювання можливості покрити понесені витрати внаслідок хижацького ціноутворення, то споживачам та їх інтересам, в принципі, не повинно бути завдано шкоди.

При цьому, Суд дотримувався більш традиційного підходу: стаття 102 ДФЄС стосується не тільки дій, які можуть заподіяти безпосередньої шкоди споживачам, але також i тих, які завдають їм шкоди через свій вплив на ефективну структуру конкуренції. На підставі цього він постановив, що доказ існування можливості покриття понесених витрат не $є$ обов'язковою попередньою умовою для висновку про те, що хижацьке ціноутворення $\epsilon$ 
зловживанням. Суд також заявив, що Комісія має змогу досліджувати існування можливості покриття витрат домінуючим суб'єктом господарювання у певних випадках. Наприклад, коли хижацька ціна нижче середніх змінних витрат, доказ ймовірного покриття витрат може бути використано для спростування будь-яких економічних виправдань, які домінуючий суб’єкт господарювання може зазначити для обгрунтування своїх низьких цін (наприклад, що він продає застарілі запаси); а коли хижацька ціна вище середніх змінних витрат і нижче середніх загальних витрат, доказ ймовірного покриття витрат може допомогти у доведенні наявності у такого суб’єкта господарювання стратегії з усунення конкурентів. У такому світлі, існування можливості встановлення монопольно високої ціни (a, отже, потенційної шкоди споживачам) є тільки свідченням того, що така практика є зловживанням, але не складовим елементом зловживання [5]. Узагальнюючи це, можна дійти висновку, що Суд на даний час не вимагає від Комісії доводити наявність обмеження доступу на ринок, а також існування завданої в результаті цього шкоди споживачам.

Той факт, що Комісія використовує у своїй практиці здебільшого підхід, заснований на виявленні ймовірного заподіяння шкоди споживачеві перед ініціюванням розгляду справи про зловживання домінуючим становищем, який відрізняється від підходу Суду, який грунтується на завданій шкоді конкурентному процесу, породжує деякі потенційно складні питання. По-перше, національні суди та національні антимонопольні органи зобов'язані дотримуватися тлумачення Судом СС статті 102 ДФСС, і при цьому для них не мають імперативного характеру Керівні принципи для Комісії у правозастосовній діяльності щодо статті 102 ДФСС. Це означає, що може існувати ризик розбіжностей в аналізі аналогічної практики у тих випадках, коли Комісія застосовуватиме стандарти, відмінні від тих, які застосовують національні антимонопольні відомства. Безсумнівно, Комісія може вжити заходів для забезпечення однакового тлумачення статті 102 ДФСС, але це не може запобігти розбіжності у поглядах на тлумачення зловживання, якщо національні суди або влада хоче діяти таким чином. При цьому одним 3 результатів діяльності Свропейської мережі 3 питань конкуренції стало те, що національні антимонопольні відомства намагаються розробити універсальні підходи, і це може спонукати національні органи з питань конкуренції слідувати загальному підходу Комісії.

По-друге, здається малоймовірним, що проблема розбіжності у практиці двох інституцій буде вирішена в короткостроковій перспективі. Це пов'язано 3 тим, що Комісія просто не буде застосовувати статтю 102 ДФСС у певних випадках, як це вона робила в минулому, а це, у свою чергу, означає, що встановлена практика Комісії та Суду не буде переглянута або переосмислена. 
Незважаючи на це, навряд чи юридичні радники скаржників забудуть відповідну практику право тільки тому, що вона не згадана Комісією, а отже, може виникнути приватний судовий процес, через те, що скарги в антимонопольні органи будуть відхилятися антимонопольними органами.

У цьому контексті заслуговує на увагу актуальна практика Суду СС у справах про зловживання домінуючим становищем. Одна 3 таких справ стосується норм, що регулюють позови про відшкодування шкоди за порушення антимонопольного законодавства. У справі Cogeco Communications [7] Суд СС виніс рішення від 28 березня 2019 року за преюдиційним запитом щодо Директиви 2014/104 про певні норми, щуо регулюють позови щуодо відикодування шкоди відповідно до національного законодавства за порушення положень законодавства про конкурениію держав-членів та Європейського Союз (Директива 2014/104) [8]. Спір в рамках основного судового розгляду стосувався позову про відшкодування шкоди, яку компанія Cogeco Communications Inc. нібито понесла у результаті антиконкурентної діяльності компанії Sport TV Portugal SA. Позов був поданий 27 лютого 2015 року після рішення антимонопольного органу, згідно з яким на компанію Sport TV Portugal було накладено штраф за зловживання своїм домінуючим становищем на ринку спортивних телеканалів преміум-класу у період з 2006 по 2011 роки.

Однак, португальське законодавство про позадоговірну відповідальність, яке застосовувалось до спору під час основного розгляду, передбачає трирічний строк позовної давності, який, на думку компанії Sport TV Portugal, розпочався як тільки компанія Cogeco Communications отримала всю необхідну інформацію, щоб оцінити, чи дійсно вона має право на відшкодування шкоди, що зрештою мало бути підставою для відмови у позові, оскільки строк позовної давності сплив. Хоча Директива 2014/104 містить, серед іншого, положення щодо строків позовної давності в контексті позовів про відшкодування шкоди внаслідок порушення законодавства про конкуренцію, на момент подачі позову вона ще не була імплементована у правову систему Португалії. Результат спору, як наслідок, залежав від того чи застосовуються положення Директиви 2014/104. Таким чином, національний суд Португалії направив преюдиційний запит щодо цього питання.

Щодо застосування ratione temporis Директиви 2014/104, Суд ЄС постановив, що якщо держави-члени вирішили, що положення їх національної правової системи, які імплементують процесуальні положення цієї директиви, не застосовуються до позовів про відшкодування шкоди, які подані до дати набрання чинності відповідними національним положеннями, позови, подані після 26 грудня 2014 року, але до дати закінчення терміну, встановленого для імплементації цієї директиви, як і раніше регулюються виключно національними 
процесуальними нормами, які вже діяли до імплементації директиви. Те ж саме стосується національних положень, які прийняті державами-членами відповідно до статті 21 Директиви 2014/104, щоб відповідати матеріальним положенням даної директиви, оскільки, як випливає 3 формулювання статті 22 (1) цієї Директиви, такі національні положення не мають зворотної сили. За цих обставин Суд постановив, що Директива 2014/104 повинна тлумачитися як така, що не застосовується до спору в основному судовому розгляді.

Можна дійти висновку, що у разі відсутності норм ЄС, які регулюють позови про відшкодування шкоди у зв'язку 3 порушенням антимонопольного законодавства, національна правова система кожної держави-члена повинна передбачати детальні норми, що регулюють здійснення права на відшкодування шкоди в результаті зловживання домінуючим становищем, включаючи, зокрема, норми щодо строків позовної давності за умови дотримання принципів еквівалентності та ефективності. Ці норми не повинні ставити під загрозу ефективне застосування статті 102 ДФЄС. У зв'язку з цим необхідно враховувати специфіку справ, пов'язаних із антимонопольним законодавством, i, зокрема, той факт, що пред’явлення позовів про відшкодування шкоди у зв'язку 3 порушеннями законодавства ЄC про конкуренцію вимагає, в принципі, комплексного фактичного та економічного аналізу. Таким чином, Суд постановив, що стаття 102 ДФЄС і принцип ефективності повинні тлумачитись як такі, що перешкоджають застосуванню національного законодавства, яке, поперше, передбачає, що строк позовної давності щодо позовів про відшкодування шкоди становить три роки і починається з дати, коли потерпіла сторона дізналася про своє право на відшкодування шкоди, навіть якщо не знала відповідальної особи, i, по-друге, не передбачає ніякої можливості призупинити або перервати цей строк під час розгляду в національному антимонопольному органі.

Крім того, вбачається доцільним здійснити аналіз рішення від 6 вересня 2017 року у справі Intel v Commission [9], яка надала Суду СС можливість, засідаючи Великою палатою, визначити територіальну юрисдикцію Комісії щодо притягнення до відповідальності за зловживання домінуючим становищем. Спір виник в результаті рішення Комісії про накладення штрафу в розмірі 1,06 млрд євро на компанію Intel, американського виробника центральних процесорів (ЦП), за зловживання своїм домінуючим становищем на світовому ринку процесорів з 86-ти бітною архітектурою, зокрема, шляхом надання знижок виробникам комплектного обладнання в обмін на використання виключно продукціï Intel. Суд ЄС скасував рішення Суду загальної юрисдикції щодо відхилення позову Intel щодо скасування відповідного рішення Комісії. Суд СС дійшов висновку, що Суд загальної юрисдикції у своєму апеляційному рішенні не розглянув всі аргументи, викладені Intel щодо того, чи можуть розглядатися 
знижки, які надає Intel деяким своїм клієнтам, як такі, що обмежують конкуренцію.

Що стосується питання, піднятого Intel щодо того, чи володіє Комісія юрисдикцією для виявлення і притягнення до відповідальності за дії, вчинені за межами Європейського Союзу, Суд нагадав, що той факт, що суб'єкт господарювання, який бере участь у певній угоді, знаходиться в третій країні, не перешкоджає застосуванню статті 101 ДФЄС, якщо ця угода діє на території внутрішнього ринку СС. В цьому випадку Комісія в оспорюваному рішенні обгрунтувала свою юрисдикцію для застосуванні статті 102 ДФСС до угод, укладених Intel з великим виробником комплектного обладнання (OEM) в Китаї, на доктрині «кваліфікованих наслідків» діяльності на території Європейської економічної зони. Суд СС також підтвердив, що цей критерій може слугувати підставою для юрисдикції Комісії у застосуванні антимонопольного законодавства ЄС відповідно до міжнародного публічного права, коли можна передбачити, що така діяльність здійснить негайний та істотний вплив на ринок ЄС. Суд зазначив, що для того, щоб критерій передбачуваності був дотриманий, як i в даному випадку, достатньо взяти до уваги можливі наслідки такої діяльності для конкуренції на відповідному ринку. Незважаючи на те, що процесори призначалися для постачання в Китай, Суд встановив, що поведінка Intel $€$ частиною загальної антиконкурентної стратегії, спрямованої на закриття доступу їі єдиного конкурента до найбільш важливих каналів продажів на ринку, і зазначив, що продаж комп'ютерів, укомплектованих такими процесорами було, зокрема, заплановано на території Свропейської економічної зони.

Щодо клопотання про істотне процесуальне порушення, що порушує права Intel на захист, то компанія Intel фактично піддала критиці розгляд клопотання Загальним судом, у якому вона скаржилася, в першу чергу, на неспроможність Комісії заслухати належним чином під час адміністративної процедури керівника одного 3 найбільших клієнтів Intel. В цьому контексті Суд встановив, що Загальний суд припустився помилки у застосуванні права, провівши відмінність між офіційними слуханнями, які підпадають, зокрема, під дію статті 19 (1) Регламенту № 1/2003 [10], і неформальними співбесідами, які не підпадають під дію даного положення. Комісія зобов'язана записувати в будь-якій формі за своїм вибором будь-яке надання свідчень, яке вона організувала відповідно до даного положення з метою збору інформації, що відноситься до предмету розслідування. Однак, Суд наголосив, що оскільки в оспорюваному рішенні Комісія не спиралася на інформацію, зібрану під час відповідного інтерв’ю, компанія Intel повинна була довести, що, якби вона могла посилатися на належний запис цього інтерв’ю, то він міг би вплинути на результат розслідування Комісії у даній справі. Суд постановив, що у даній справі таких доказів не було надано. 
Щодо оцінки зловживань, Суд встановив, що дії Intel по відношенню до своїх торговельних партнерів, спрямована на усунення свого єдиного серйозного конкурента з ринку, полягали, по-перше, в наданні знижок чотирьом основним ОЕМ-виробникам за умови, що вони куплять усі або майже усі процесори із 86ти бітною архітектурою в Intel, i, по-друге, у здійсненні платежів OEMвиробникам, щоб вони затримували, скасовували або обмежували продаж певних продуктів, оснащених процесори цього конкурента. В оскаржуваному рішенні Суд загальної юрисдикції вважав, що питання про те, чи можна віднести ексклюзивну знижку, надану суб'єктом господарювання, що займає домінуюче становище, до категорії «зловживань» не залежить від аналізу обставин справи, спрямованого на визначенні здатності такої знижки обмежити конкуренцію, оскільки такі знижки за своєю природою здатні обмежувати конкуренцію.

Однак, Суд встановив, що Комісія провела ретельне дослідження обставин справи в оспорюваному рішенні, i на цій підставі дійшла висновку, що ефективний конкурент на відповідному мав би запропонувати такі ціни у зв'язку з цими знижками, які були б нерентабельними. Отже, на думку Суду, критерій ефективності конкурентів зіграв важливу роль в оцінці Комісією того, чи здатна дана практика вплинути на доступ потенційних конкурентів на відповідний ринок. Таким чином, Суд постановив, що Суд загальної юрисдикції повинен був дослідити всі аргументи Intel щодо застосування критерію ефективності конкурента 3 метою демонстрації наявності нібито помилок з боку Комісії в контексті цього тесту. В результаті, Суд СС скасував оскаржуване рішення і повернув справу до Суду загальної юрисдикції, щоб той міг дослідити у світлі аргументів, висунутих Intel, питання чи можуть такі знижки обмежити конкуренцію.

Висновки. Отже, слід зазначити, що внесок Суду СС у вироблення єдиної правозастосовної практики важко переоцінити. Він не тільки дає тлумачення положень статей про конкуренцію, а й слугує новатором у становленні певної практики. В результаті такої практики його рішень та тлумачень мають дотримуватися не тільки сторони у спорі, а й Європейська Комісія, національні антимонопольні відомства держав-членів ЄС, національні суди і сам Суд ЄС. Зменшення кількості справ з року в рік свідчить про те, що Європейська Комісія на початковому етапі ефективно кваліфікує ситуацію та посилається на попередні рішення і тлумачення Суду СС. Тим не менш, не слід забувати і про практику Суду загальної юрисдикції, який слугує першою інстанцією, рішення якої можуть бути скасовані уже самим Судом СС. Відповідно до звіту за 2019 рік кількість справ щодо порушень конкуренційного законодавства ЄС знизилась за останні п'ять років, що свідчить про те, що реформа Суду була успішною, адже розвантажила його, не дивлячись на певні тенденції із збільшенням кількості відповідних справ у 2019 році. 


\section{Jimepamypa:}

1. A legal-historical review of the EU competition rules [Електронний pecypc] // British Institute of International and Comparative Law. - 2014. - Режим доступу до ресурсу: http://dro.dur.ac.uk/17253/.

2. Case T-Mobile Netherlands BV, KPN Mobile NV, Orange Nederland NV and Vodafone Libertel NV v Raad van bestuur van de Nederlandse Mededingingsautoriteit. Режим доступу до pecypcy:https://curia.europa.eu/juris/document/document.jsf;jsessionid=894B556F77434641DC3655 67F986AE20?text $=\&$ docid $=74817 \&$ pageIndex $=0 \&$ doclang $=$ en $\&$ mode $=1$ st $\&$ dir $=\& o c c=$ first $\&$ part $=1 \&$ cid $=2155812$.

3. Judgment of the Court (Konkurrensverket v TeliaSonera Sverige) [Електронний ресурс] - Режим доступу до ресурсу: https://eur-lex.europa.eu/legal-content/EN/ALL/?uri=CELEX\% 3А62009CJ0052.

4. Judgment of the General Court (Intel Corp. v Commission) [Електронний ресурс] Режим доступу до ресурсу: http://curia.europa.eu/juris/liste.jsf?num=T-286/09.

5 . Monti G. Article 82 EC: What Future for the Effects-Based Approach? / Giorgio Monti. // Journal of European Competition Law \& Practice, 2010.

6. Case C-202/07 P France Te'le'com SA v Commission Opinion of 25 September 2008, para 74.

7. ECJ, Cogeco Communications Judgment ECLI:EU:C:2019:263 [Електронний ресурс] Режим доступу до ресурсу: https://curia.europa.eu/juris/documents.jsf?language=EN\&critereEcli= ECLI:EU:C:2019:263.

8. Directive 2014/104/EU of the European Parliament and of the Council of 26 November 2014 on certain rules governing actions for damages under national law for infringements of the competition law provisions of the Member States and of the European Union (OJ 2014 L 349, p. 1).

9. ECJ, Intel v Commission, ECLI:EU:C:2017:632 [Електронний ресурс] - Режим доступу до ресурсу: https://curia.europa.eu/juris/documents.jsf?language=EN\&critereEcli= ECLI:EU:C:2017:632.

10. Council Regulation (EC) No 1/2003 of 16 December 2002 on the implementation of the rules on competition laid down in Articles 81 and 82 of the Treaty [Електронний ресурс] - Режим доступу до ресурсу: https://eur-lex.europa.eu/legal-content/EN/ALL/?uri=CELEX:32003R0001.

\section{References:}

1. A legal-historical review of the EU competition rules [Електронний ресурс] // British Institute of International and Comparative Law. - 2014. Retrieved from http://dro.dur.ac.uk/17253/ [in English].

2. Case T-Mobile Netherlands BV, KPN Mobile NV, Orange Nederland NV and Vodafone Libertel NV v Raad van bestuur van de Nederlandse Mededingingsautoriteit. Retrieved from https://curia.europa.eu/juris/document/document.jsf;jsessionid=894B556F77434641DC365567F986A E20?text $=\&$ docid $=74817 \&$ pageIndex $=0 \&$ doclang=en $\&$ mode $=1$ st $\&$ dir $=\&$ occ $=$ first $\&$ part $=1 \&$ cid $=2155$ 812 [in English].

3. Judgment of the Court (Konkurrensverket $v$ TeliaSonera Sverige). Retrieved from https://eur-lex.europa.eu/legal-content/EN/ALL/?uri=CELEX\%3A62009CJ0052 [in English].

4. Judgment of the General Court (Intel Corp. v Commission). Retrieved from http://curia.europa.eu/juris/liste.jsf?num=T-286/09 [in English].

5. Monti G. Article 82 EC: What Future for the Effects-Based Approach? / Giorgio Monti. // Journal of European Competition Law \& Practice, 2010. 
6. Case C-202/07 P France Te'le'com SA v Commission Opinion of 25 September 2008, para 74.

7. ECJ, Cogeco Communications Judgment ECLI:EU:C:2019:263. Retrieved from https://curia.europa.eu/juris/documents.jsf?language=EN\&critereEcli=ECLI:EU:C:2019:263 [in English].

8. Directive 2014/104/EU of the European Parliament and of the Council of 26 November 2014 on certain rules governing actions for damages under national law for infringements of the competition law provisions of the Member States and of the European Union (OJ 2014 L 349, p. 1).

9. ECJ, Intel v Commission, ECLI:EU:C:2017:632. Retrieved from https://curia.europa.eu/juris/documents.jsf?language=EN\&critereEcli=ECLI:EU:C:2017:632 [in English].

10 . Council Regulation (EC) No 1/2003 of 16 December 2002 on the implementation of the rules on competition laid down in Articles 81 and 82 of the Treaty. Retrieved from: https://eurlex.europa.eu/legal-content/EN/ALL/?uri=CELEX:32003R0001 [in English]. 